\title{
POPULISM IN FOREIGN POLICY: SHIFTING PARADIGMS IN GREEK POLITICAL PARTIES
}

\section{Theofanis EXADAKTYLOS*}

\section{Abstract}

Has populism affected the foreign policy narratives of Greek political parties? The purpose of this article is to present a different perspective of foreign policy looking at policy paradigms (beliefs, norms and values) that shape its outlook and political narratives. These paradigms develop inter alia inside political parties themselves. Given the presence of both left-wing and right-wing populism, Greece becomes an interesting testing ground to explore the effect of populism on foreign policy paradigms. In connecting parties and political positions in the realm of foreign policy, this article renders the lens of populism to examine the foundations of these political positions in foreign policy narratives. Investigating the party manifestos of Greek political parties for all elections between 2009 and 2015 can determine changes, continuity and shifts in policy paradigms and assess the impact of populism in the creation of foreign policy narratives. Populism has led to a more polarised foreign policy narrative to be developed reflecting the deep ideological polarisation that the advent of populist parties as serious contenders to government have caused in Greece.

Keywords: Populism, foreign policy, Greece, political parties, policy paradigms, crisis.

\section{DIŞ POLITIIKADA POPULIZM: YUNAN SIYYASI PARTILLEIINDE DEĞISSEN PARADÍGMALAR}

\author{
$\ddot{O} z$
}

Popülizm, Yunan siyasi partilerinin dış politika anlatılarını etkilemekte midir? Bu makalenin amacı, bakış açılarını ve siyasi anlatıları etkileyen politika paradigmalarının (inançlar, normlar ve değerler) dış politikaya bakışı konusunda farkll bir perspektif sunmaktır. Bu paradigmalar, dĭgerleriyle birlikte siyasi partilerin içinde gelişirler. Yunanistan, hem să̆ hem de sol popülizmin varlı̆̆ göz önüne alındı̆̆ında, popülizmin dış politika

\footnotetext{
* Dr, Reader in European Politics University of Surrey, e-mail: t.exadaktylos@surrey.ac.uk.
} 
paradigmaları üzerindeki etkisinin araştırılmasında, ilginç bir inceleme alanı haline gelmektedir. Bu makale, popülist yaklaşım, partiler ve onların dış politika alanındaki pozisyonlarıla bağlantılı olarak, dış politika anlatılarındaki siyasi pozisyon kaynaklarının incelenmesine odaklanmaktadır. Yunan siyasi partilerinin, 2009-15 yılları arasında gerçekleşen seçimlerde kullandıklart parti manifestolarını incelenmesiyle, siyasi paradigmalarındaki istikrar ve değişimleri ve popülizmin diş politika anlatılarının şekillenmesine etkisini değerlendirmek mümkündür. Yunanistan'da popülizm, popülist partilerin hükümetin ciddi rakipleri olarak ortaya çıkmasından kaynaklanan ideolojik bir kutuplaşmay göstermekle birlikte, daha derin kutuplaşmış bir dış politika anlatısina da neden olmuştur.

Anahtar Kelimeler: Popülizm, dış politika, Yunanistan, siyasi partiler, politika paradigmalarl, kriz.

\section{Introduction $^{1}$}

Foreign policy is a multifaceted policy domain that tends to be considered as unique, or sui generis, due to reference to dogmas, high diplomacy and strategic culture. It flows naturally then to examine this domain from an international relations perspective or using foreign policy analysis tools. This approach helps with understanding the complexities of the international system and hence the role of specific countries within it, as well as the deeper and multifaceted character of policy design, especially high politics. Nonetheless, this approach does not allow identifying and following the evolution of values, paradigms and beliefs over time inside the different processes of policy design and the interactions of foreign policy actors in the micro-level and meso-level (Exadaktylos, 2015). In other words, this approach examines countries vis-à-vis their role in the international system (or within their bilateral relations) without taking into account the way different perspectives in designing policy and belief systems create unique policy narratives that are diffused through foreign policy paradigms.

The purpose of this article is to present Greek foreign policy as a paradigm that is shaped inside political parties and to examine the extent to which a populist narrative has been institutionalised in its manifestation. The research question then becomes how populist frames affect the creation of foreign policy paradigms in the narratives of political parties? Greece, which experienced the rise of both left- and right-wing populist parties in the context of the financial crisis (2009-16) becomes an interesting testing ground to study this effect. In addition, the combination of the Greek debt crisis and the rise of SYRIZA and

\footnotetext{
${ }^{1}$ I would like to thank the anonymous reviewers for their kind feedback that helped shape the final draft of the article, as well as Münevver Cebeci for her unconditional guidance, help and eye for detail.
} 
Independent Greeks (ANEL) to government as populist parties of the left and the right in a coalition allows the examination of the way narratives compete and speak to each other. Within this context, it is important to examine foreign policy not as a domain that requires special treatment but rather treatment as any other public policy using classic analytical tools. Hence, just like any other public policy, foreign policy incorporates policy paradigms that are transferable from a general analytical perspective in terms of terminologies and typologies and are identified through overlapping domestic, European and international political processes. At this stage it is important to define the term "paradigm", how it contributes to the manifestation of the policy, how it demarcates policy design procedures and how it impacts its implementation.

From a standard point of view, policy paradigms can be defined as frames and rules of ideas and beliefs that characterise foreign policy making (Hall, 1993). As such, it can be argued that foreign policy is not different to any other public policy and that the term "policy paradigm" can be extended to define the system of beliefs that characterises not only the political system but also the actors that contribute to policy making (Sabatier and Jenkins-Smith, 1999). Hence, paradigms become roadmaps utilised by bureaucrats, experts and political actors (Béland, 2005) and become the cohesive elements between political ideas and processes of policy making. Maintaining the same paradigms allows political actors to make similar choices even within differentiated political circumstances (Berman, 1998) and as such to bring action under comparable frameworks. Policy paradigms are developed in think tanks, academic research institutes and schools of public policy, as well as in other political actors (such as political parties) that interact with internal and external environments creating those paradigms through policy implementation or through formal or informal socialisation and learning. In essence, paradigms have a national founding principle but they can be affected by the circulation of ideas at the international level (Béland, 2005). Hence, paradigms oscillate between national custom and international influences in a two-way process (Schmidt, 2002). Finally, the presence of old paradigms and the emergence of new ones frame political narratives, which in turn, helps amplify and cascade them in lower strata of decision-making.

In the following sections, the article explores public policy analysis tools and how these can be used to examine foreign policy incidents, including the way through which paradigms are translated into tangible policy proposals. It continues by presenting a framework for populist narratives in terms of blameshifting and exclusivity. The article does not explore debates around populism as it accepts that populism is omnipresent in Greek politics (Vasilopoulou et al. 2014) and hence transcends ideological boundaries (i.e. both left, centre and right). It suffices to say that populism exists as a paradigm and as such it affects 
policies, politics and political framing. Using document analysis to categorise narratives in the party manifestos in five electoral contests (2009, May 2012, June 2012, January 2015 and September 2015) the article presents an empirical analysis of the thematic frames of Greek foreign policy narratives as these appear in the positions of the Greek political parties consistently present in Parliament between 2009 and 2015, when populism was at its highest in Greece (Katsanidou and Lefkofridi, 2020) and in the context of the financial crisis formally ending before the 2019 election and the demise of SYRIZA.

\section{Populism and Paradigmatic development in foreign policy}

Populism is a highly contested concept with a number of different definitions (Mudde and Kaltwasser, 2012:149). Following Mudde's (2004:543) widely cited definition, populism is "a thin-centred ideology ${ }^{2}$ that considers society to be ultimately separated into two homogeneous and antagonistic groups, 'the pure people' versus 'the corrupt elite', and which argues that politics should be an expression of the general will of the people". Populism has also been defined as a discursive style rather than an ideology. Gidron and Bonikowski (2013), contend that such views on populism are more related to a political discourse that situates politics within the construction of "the people versus the elites" binary, than to ideology. Others define populism as a mode of political strategy that is characterized by "policy choices, political organization, and forms of mobilization" (Gidron and Bonikowski, 2013: 10). Weyland (2001: 14) asserts that "populism is best defined as a political strategy" because "political strategies are characterized by the power capability that types of rulers use to sustain themselves politically". Populism has thus been regarded as "a means of building and maintaining political power based on the mass mobilization of supporters" (Barr, 2018: 54).

Wehner and Thies (2020) also define populism as a thin-centred ideology and they compare thick and thin ideologies of populism in foreign policy. Wojczewski (2020a: 294) identifies populism as a discourse, arguing that "the populist notion of the people can also be a subjectivity that is constituted and reproduced via the discourse of foreign policy". Plagemann and Destradi (2019), in their work on the case of India, claim that populism as a political style - i.e., ideational, is a more appropriate way of analysing its impact on foreign policy. However, Cadier and Lequesne (2020) worked on populism in the foreign policy of the EU through populism as a strategy. In this article, populism is used as both a political strategy and a discourse.

2 "Thin-centered ideologies are those that do not provide answers to all the major sociopolitical questions, and could therefore be compatible with other, more extensively developed political belief systems, such as socialism or liberalism." (Gidron and Bonikowski 2013: 6). 
In the literature there are two research strands concerning the role of political parties in foreign policy (Chryssogelos, 2017). The first one focuses on how the ideology of political parties affects foreign policy and the second one focuses on how "institutional settings allow parties to exert influence over foreign policy" (Chryssogelos, 2017). With regard to the impact of populist political parties on foreign policy, the literature mainly focuses on the radical right but it should also be noted that radical left parties might also pursue populist strategies. For example, Verbeek and Zaslove (2015) examine populist radical right's impact on foreign policies from the perspective of comparative politics. The literature also examines the impact of coalitions on populist inclinations in conducting foreign policy. Kaarbo's (1996; 2008; 2012) works on coalitions and foreign policy argue that coalition governments are in a tendency to exhibit more extreme attitudes in their foreign policy. Wojczewski's (2020b) work on Indian populism, nationalism and its effects on Indian foreign policy also furthers the argument that there is a link between coalitions and rising populism. This article's approach is closer to the first strand of research on foreign policy and populism as it is more interested in the ideological aspect of the impact of political parties on foreign policy.

For the purposes of this article, foreign policy is defined as a wider policy coordination framework that includes financial, political and military means (Jorgensen, 1997; Smith, 1999; also in Tonra and Christiansen, 2004). Using this definition as a starting point, foreign policy can be influenced not only by institutions that produce specific ideas leading to political change (Goldstein and Keohane, 1993), but also by the presence of epistemic communities that produce new ideas based on common beliefs (Haas, 1990; Haas, 1992). These interactions produce common norms, values and beliefs that are then translated into policy making. Hence, when policy paradigms emerge, macro-level elements interact combining cognitive and normative frameworks. According to Surel (2000: 496), these frameworks consolidate paradigms (Hall, 1993), belief systems (Sabatier, 1998; Sabatier and Jenkins-Smith, 1999) and réféntiels (Jobert and Muller, 1987). In this way, paradigms help shape worldviews, identities, actions and modus operandi. A set of axiomatic principles, specific rules, policies and implementation tools is included within a paradigm. Regarding foreign policy, the main question is whether paradigms are continuous or whether there is a generic paradigm to which policy actors contribute. In other words, is it possible to have paradigms that compete with each other? And therefore, how can we examine foreign policy using the existing tools from public policy analysis?

Assuming that foreign policy is identified as "an attempt to design, manage and control the external activities of a state as to protect and advance agreed and reconciled objectives" (Allen, 1998: 43-44), we immediately infer the 
establishment of an economic, political, social and cultural discursive forum. Therefore, foreign policy cannot be considered as a unitary, one-dimensional variable (Exadaktylos, 2012) independent of its policy paradigms. Instead foreign policy can be expressed as a vector or a compound variable of four constitutive components: (a) actors of foreign policy; (b) instruments of foreign policy; (c) decision-making procedures; and, (d) foreign policy paradigms (norms, rules and deep core values ${ }^{3}$ ). Each of these four components can be analysed independently or in conjunction with the interaction between some or all four components, much like in any other public policy. In this way, foreign policy becomes a system of interaction between the components above and paradigms become springboards of action. Actos, instruments and procedures are thus bound by norms, rules and deep core values, meaning that narratives that shape paradigms play an important role in determining the outlook of any policy.

Looking at foreign policy specifically, and based on the studies of Jobert and Muller (1987), Hall (1993), Levy (1994), Sabatier (1998), Sabatier and Jenkins-Smith (1999) and Surel (2000), policy paradigms can be considered those basic cognitive and normative frameworks that influence actors in the way they make their decisions, as well as instruments and procedures that are implemented in policy making. Excluding the cognitive and normative impact of paradigms on creating foreign policy actions would be a severe oversight, as policy paradigms incorporate the worldviews on which these actions are based. A paradigm approach to foreign policy focuses on policy changes, policy complexities and policy adaptations (Surel, 2000: 503). Following the typology proposed by Sabatier and Jenkins-Smith (1999), policy paradigms can be classified as follows.

Deep core: Those refer to paradigms in the core of actor identity or fundamental axioms in policy making, such as neutrality, pacifism or nonintervention (Diez, 2005; Kirchner, 2006). As such they remain relatively stable over time and define long-term policy narratives.

Policy core: These are paradigms central to specific policy areas and provide the basic principles for strategic planning. These may include for example, multilateralism, bilateral agreements, using the UN Security Council, using the HR/VP for CSDP at the European Union (EU) level (Biscop et al. 2005; Lucarelli and Manners, 2006; Smith, 2006). Policy core paradigms may change more frequently as they are defined by ideological narratives and affected by change in government or leadership. 
Secondary aspects: These are constitutive elements that are necessary for successfully implementing policy core paradigms. They may include for example, seeking consensus across political parties, informing the public through public consultation processes and parliamentary scrutiny procedures (Smith, 2004), splitting the policy costs, specialization of actor expertise, among others. These are more prone to change and may shift more frequently as a result of current affairs and day-to-day reactions to events.

Regarding foreign policy, specific policy paradigms that stem from specific principles, norms and beliefs and that become dominant paradigms (Radaelli, 1998; Howorth, 2004) frame the discourses that emerge in foreign policy at the national level. These correspond to the ways that different countries, in this case of Greece, perceive their actorness and the types of mechanisms they develop for foreign policy. At this point, it is appropriate to examine how change in political leadership and the rise of populism can shift existing paradigms, not only in the policy core and secondary aspects, but also in the deep core side of things.

\section{Populist narratives in policy making in Greece}

The 2008 global financial crisis deeply affected Greece as a country, pushing it to sign memoranda of understanding for financial assistance (MoUs), known as bailout agreements. These included financial aid under conditionality of reform, austerity and cutbacks in fiscal expenses. The bailouts and the terms and conditions attached to them had a significant socio-political knock-on effect, especially in welfare state provisions, e.g. in health and education. Large segments of the population found themselves in a disadvantageous position due to cuts in benefits and salaries, lay-offs and taxation increases. The political aspect of those cuts manifested itself intensely through waves of strikes, mass protesting and citizen mobilization that frequently paralyzed the country (Exadaktylos and Zahariadis, 2014). During the early years of the crisis, such reactions even created the prospects for the country to exit the Eurozone and the EU. The systemic deficiency of Greece but also of the EU to handle the crisis threatened the future of European integration many times and created a new polarization between pro- and anti-Europeanism in Greece and beyond.

To examine the case of Greece in the context of the crisis and the impact of populism, the article needs to shed a critical lens on the purposes and sustainability of the austerity measures of the Greek programmes that the Troika (European Commission, European Central Bank and International Monetary Fund) agreed with the Greek government through the bailouts. In June 2013, the IMF admitted that it had underestimated the damage of austerity policies it has set as a precondition to the Greek economy. This admission triggered a continuous conflict between the IMF and the EU for managing the 
Greek debt crisis and its social implications. On the other hand, we cannot oversee the endemic problems of the country, i.e. the paradox of maintaining a democratic institutional framework without deviating from established and deeply rooted clientelistic and rent-seeking networks that characterize Greek political life (Featherstone 2011, Mitsopoulos and Pelagidis, 2011). The coexistence of these antithetic mechanisms in the period following the restoration of democracy in 1974 have assisted the establishment of a populist democratic system (Pappas, 2013) that allowed Greece to develop politically and economically in periods of international economic stability but at the same time prevented the country to become resilient to external shocks.

Hence, the theoretical concept of a "populist democracy" (Pappas, 2014) becomes extremely useful and relevant as it provides a pragmatic explanation of the reasons why Greek democracy survived almost four decades following the dictatorship but was unable to endure the global financial crisis. This conceptualisation brings populism at the epicentre of the deficiencies of Greece, and by extension, populism becomes the defining framework of the Greek political system - as mentioned, it becomes the fundamental axiom upon which the dominant political narrative is built. In other words, if populism as an ideological paradigm constitutes a manifestation of the deeper core of the Greek political system, then it is highly likely that it is also expressed through the political narrative of political actors and hence, of political parties (Vasilopoulou et al. 2014). The question then becomes how does this paradigm find an expression in times of crisis? A crisis opens up political opportunity windows to smaller actors in the system, hence it is expected that the populist dominant narrative is observed across the full spectrum of the party system, irrespective of political ideology-i.e. everyone is populist. Given that populism can be seen as the fundamental cleavage between the "innocent us" and the "evil others", the populist paradigm is expressed through the use of blame-shifting and exclusion mechanisms (Vasilopoulou et al. 2014). Given that Greece has this paradoxical clientelistic political system and access to power implies privileged access to benefits, populism will also assume different ideological shades according to the ideological position of a party in the system (Exadaktylos and Nezi, 2018). In other words, there are far-left, left, centre, right, and far right-wing populism versions.

The rise of the Greek populist democracy paradigms happened in three stages: first, with the rise of a powerful populist party in opposition, then with the rise of populism in government, and finally as a result, with the spread of

${ }^{4}$ Populist democracy is defined as "a democratic subtype in which, besides the party in office, at least the major opposition party (and even other minor parties) are also populist" (Pappas, 2014: 1). 
populism to all other political parties (Pappas, 2014: 7-8). The political platforms on which PASOK on the centre-left competed with New Democracy on the centre-right and with other political parties were in their foundations populist othering the neoliberal foundations of the post-dictatorial democratic system. Party competition developed by extension on a binary logic of "we, the people" against the "appropriating establishment". The rise of PASOK in power in 1981 and its establishment in the political system reinforced this logic. Hence, it created the perception of two "populist" camps and populism became the sole legitimate means of political competition. In other words, populism became the only paradigm which a political party could essentially use to compete for and maintain itself in power (Exadaktylos and Nezi, 2018).

Previous research (Vasilopoulou et al. 2014) examined this main division in party competition according to which the basic political cleavage in Greek society is "we, the people" against "the appropriating establishment", and hence populism is located in the narratives of political actors. Given the opening of windows of opportunities for smaller political actors in the system during periods of crisis, there is a wider diffusion of the populist paradigm across the political spectrum independent of ideology. The basic mechanism of populism is the reference to the "people" (Taggart, 2000) that aims to mobilize not only a specific class (by Marxist standards) but the masses in general against anything that is classified as an "enemy". Hence, the basic referential paradigm is the shifting of blame which is based on a rhetoric of excluding oneself against other political groups (Jagers and Walgrave, 2007) from assuming responsibility of action. This can be achieved through problem denial, problem acceptance but responsibility denial, or accepting both the problem and the responsibility (Hood et al 2009).

Responsibility and blame attribution is an essential tool at the disposal of political actors that use populism as a means of maintaining the status quo and their political legitimation. The blame-shifting game therefore builds on the question of who is responsible for a crisis, targeting a range of "others". The rhetoric differs however, in the way dominant groups and dominated groups are presented and in the way "elites" are excluded. The differentiation depends on the access to power and the positioning on the party system continuum. Following the restoration of democracy in 1974, access to power was concentrated in the hands of two main parties alternating in government. This situation consolidated a deep cleavage between these two main parties in terms of access to power and access to the benefits of governing, and the smaller parties which did not have this opportunity or access (Vasilopoulou et al. 2014). Hence, the expression of populism through the shifting of blame differs based on the position of the political party in the party system, between those 
mainstream parties with access to benefits of power, and those at the fringes of the system that have no access.

Two patterns can be foreseen with reference to shifting the blame: (a) mainstream, in the form of a targeted shift to few handpicked actors, and (b) non-conventional, in the form of widespread blame-shifting to a spectrum of different actors. In the Greek party system the differentiation exists in the degree of targeted versus widespread blame-shifting (Exadaktylos and Nezi, 2018). During the financial crisis, the two main parties (PASOK and ND) had a tendency not only to blame each other but also to blame the EU and the international environment despite their pro-European positions. This was intentional to highlight the international side of the crisis, that it was imported, and as such to release themselves from taking up the blame as governing parties and accountable to their voters. Targeting other interests (e.g. banking, business and investment) was there but it was not as extensive. On the other hand, smaller parties at the fringe or margins of the system had a wider spread of actors to shed the blame. They were oscillating between blaming external actors and blaming mainstream parties for colluding with these external interests. External actors were presented as usurpers, imperialists and expansionists and the mainstream parties as traitors and responsible for 'selling out' Greece to foreigners. For example, parties like the Communist Party of Greece (KKE) was shifting the bulk of the blame to PASOK as a governing party and simultaneously to ND as an opposition party and vice versa, precisely due to the fact that these two dominated the political system since the restoration of democracy, hence represented the system itself. At the same time KKE was blaming external elites and internal interests and the party system as a whole. It highlighted the collaboration, i.e. the collusion of the two main parties with these elites and interest groups.

Respectively, SYRIZA at the beginning of the crisis shifted the blame massively towards PASOK compared to other parties at the fringes. This did not come as a surprise, given that the disenfranchised PASOK voters of 20092012 were potential SYRIZA voters. Being a conglomerate of different leftwing tangents it had extensions into PASOK and KKE voting pools. Without naming ND, SYRIZA was blaming the two-party system as a concept and its dominance in the past three decades. It also targeted specific interest groups as ideologically expected. However, it did not do so as much with external elites, concentrating more on the collusion of the two main parties with internal interests, given that at first stage the road to power was linked to the weakening of party competitors internally.

In general, previous research (Vasilopoulou et al. 2014) concluded that both the two main parties and the fringe parties were concentrating on a repeated blame-shifting, showing their common and shared belief and desire to deflect 
political accountability. They were consumed in a deflection debate from the kind of reforms necessary in sectors plagued by the crisis to who was responsible for the crisis. In this context, a party system in a semi-liberal democracy can be conceptualised, where society is divided across a populist schism. This system is characterized by an intense political polarization and conflicting policies that are expressed through an adversarial rhetoric based on the blame shifting paradigm of populism. In the mainstream parties, this shift was targeted towards parties of government and external elites. In the fringe parties, shifting was a more widespread spectrum of actors including the governing party, the main opposition party, external elites, internal special interests and the collusion between all of these actors.

In the next stage of the crisis, following the elections of May and June 2012, a high degree of electoral volatility, fragmentation of the party system, the collapse of PASOK and the rise of new political formation, including Golden Dawn, and the formation of coalition governments are observed. From 2012 until the elections in 2015 new paradigms of populism developed based more on the binary of pro- / anti-bailout and the binary of immigration versus economic liberalism rather than the classic left/right division. Within this new playing field, nationalism was an attractive paradigm considering the historical, cultural and geographic idiosyncrasies of Greece. Here, it is worth considering that populism runs through every aspect of political life, and by extension it is expected to emerge in debates of foreign policy issues.

\section{Narrative analysis of populist foreign policy paradigms in Greek political parties}

Given that prior to 2009 the party system was quite consolidated on the basis of a two-party prototype, it is interesting to examine the period after 2009 that saw new dimensions developing, such as the fragmentation of the party system and the coalition or minority governments. The examination of this period will conclude with the electoral contests of 2015 that brought in power the coalition of SYRIZA-ANEL. At a theoretical level, it is expected to observe the shifting of paradigms that existed in the previous two-party context of centre-left and centre-right to a highly polarised context between far left and the far right.

This section and the empirical analysis that follows, includes only the parties that had parliamentary representation in all five electoral contests from 2009 onwards (May/June 2012 and January/September 2015). These are PASOK (also as Democratic Alliance in September 2015), ND, KKE, SYRIZA, Independent Greeks (ANEL) and Golden Dawn (GD). LAOS disappeared after 2009, and Democratic Left appeared only in 2012, whereas, the River and the Union of Centrists only in 2015 (Table 1). This study uses a frame analysis to 
detect policy paradigms and narratives in a grounded way and determine the dominant ones in each party and across time. In terms of the research design, only the electoral manifestos of the parties are included to examine their formal position in national and foreign policy issues as presented to voters. Manifestos operate as points of reference for the electoral campaigns of their candidates to parliament as well as for mass media in the questions asked to party leaders and other candidates. At a national stage, developments are observed in the refugee crisis from Syria mainly, the shifts in Greek-Turkish relations, the conflicts around the Exclusive Economic Zone (EEZ) of Cyprus, the name of North Macedonia (known as FYROM), as well as the relations with Russia and China. The frame analysis was conducted qualitatively on the content of the manifestos, considering references to policy paradigms on the basis of deep core, policy core and secondary aspects.

Table 1: Parliamentary parties (2009-15) ranked by vote share ${ }^{5}$

\begin{tabular}{|c|c|c|c|c|}
\hline 2009 & 2012 May & 2012 June & 2015 Jan & 2015 Sept \\
\hline$P A S O K$ & $N D$ & $N D$ & SYRIZA & SYRIZA \\
\hline$N D$ & SYRIZA & SYRIZA & $N D$ & $N D$ \\
\hline$K K E$ & PASOK & PASOK & $G D$ & $G D$ \\
\hline LAOS & $A N E L$ & $A N E L$ & River & $\begin{array}{l}\text { Democratic Alliance } \\
\text { (incl. PASOK) }\end{array}$ \\
\hline \multirow[t]{4}{*}{ SYRIZA } & $K K E$ & $G D$ & $K K E$ & $K K E$ \\
\hline & $G D$ & Democratic Left & $A N E L$ & River \\
\hline & Democratic Left & $K K E$ & PASOK & $A N E L$ \\
\hline & & & & Union of Centrists \\
\hline
\end{tabular}

Source: Hellenic Parliament (2020)

\section{Elections 2009}

The 2009 elections are a starting point, presenting the status quo of the party system prior to the eruption of the Greek financial crisis and the signing of the bailout agreements. The analysis includes ND, PASOK, KKE and SYRIZA as the parties with parliamentary representation after 2009 which continued to exist in parliament in 2012. LAOS was excluded from the analysis as there is no point in studying a party that was not represented in parliament from 2012 onwards. The party system of that period comes to terms with the financial crisis abroad but the whole of the electoral campaigns takes place within the classic populist division mentioned above. Hence the basic policy paradigm in foreign policy is blame-shifting between parties. PASOK blames ND and vice versa as alternating in power, whereas KKE targets all parties and the EU, while SYRIZA blames heavily PASOK and ND together. Foreign policy is presented as a scapegoat of the crisis that requires the attention of all parties.

${ }^{5}$ In italics, those considered in the manifesto analysis as present across all parliamentary sessions. 
However, analysing the data from the party manifestos, differentiations are present in the way foreign policy issues are framed mainly on the basis of political priorities. PASOK focuses on Cyprus, the Balkans, and Turkey (PASOK, 2009). ND on Macedonia and the Aegean (New Democracy, 2009). KKE on the capitalist Euro-Atlanticism (KKE, 2009) and SYRIZA on the Balkans, the Middle East and Palestine, Cyprus and Latin America (SYRIZA, 2009).

Looking at the policy paradigms by PASOK, references to "Greece", "Europeanism", "respecting international law", "peace" and "Diaspora" in the deep core are located. The policy core is dominated by the presence of paradigms around the support for the European trajectory of Turkey and the Balkans, the customs union, the implementation of EU rules, the development policy and the participation of the $\mathrm{UN}$ in the Cyprus issue. In terms of the secondary aspects, there are plenty of references to business people for the implementation of development policy, green growth, consultations for human rights and the strategic planning to promote Greece in South Eastern Europe.

On the flipside, ND brings to its deep core paradigms references to "homeland", "red lines" that are "non-negotiable", to "crisis", to "national interest'. In the policy core paradigms the dominant ones are growth, tourism, defence spending, the Balkans accession to NATO and the EU, and the Aegean and Macedonia as growth drivers. In the secondary aspects, ND includes Egnatia Highway (joining east and west) as a commercial route, infrastructure construction, references to business people, and the power of the euro. KKE is particularly interesting, having at its deep core the "people", "class struggle", the opposition to capitalism, the popular spirit and the "detachment from the EU". In its policy core, KKE brings to the forefront the "workers", the progress of the "working class", the crack on the monopolies of the Balkans and the maintenance of manufacturing and businesses in Greece. Nonetheless, there are no particular secondary aspects but the main narrative centres around the "no sell-off" of state assets and properties. Finally, SYRIZA sets at its core the paradigms of international cooperation, the left-wing alliance in Europe, participatory politics and pacifism. At its policy core, it locates: Cyprus, due to the change of leadership; and, the UN, Palestine and Gaza, Latin America, trans-Balkan cooperation and respect of borders. In the secondary aspects, SYRIZA projects tools like dialogue, the contribution of the European Left, and events with members of communities from Latin America, Cuba and the global South, and the Balkan Ecologic Map.

In 2009, as a whole, foreign policy paradigms were based on the strict ideological positioning of the political parties, following classic and expected narratives: the party of the centre-left refers to European dimensions, the centreright party makes national references to the homeland, the communist party to 
the international class struggle and imperialism, whereas the radical left to humanistic elements.

\section{Elections 2012}

The double elections of 2012 are particularly interesting to follow the rise of SYRIZA as the main opposition party and the first effective cooperation government between ND and PASOK (including a smaller partner, the Democratic Left). Elections took place twice alongside mass protests and demonstrations against the bailout agreement measures and the creditors as well as a looming exit of Greece from the Eurozone. In the meantime, nationalism was on the rise with Golden Dawn making its first appearance in the Greek parliament bringing neo-fascist ideals and narratives. It is expected that the electoral outcome would be a result of the change of the general narratives of the left (against neoliberalism) and of the right (in favour of nationalism/patriotism). Hence, the emergence of populist paradigms will be equally more obvious, since the electoral campaigns in both elections were based on sensationalism rather than factual presentations.

Looking at the parties on the right side of the political spectrum, populism is quite evident. The main paradigm of ND has to do mostly with the "traditional foundations", "Greece", extraversion and the general framing of illegal migration. At the policy core, concepts emerge around the upgrading of the role of Greece in international relations, regional cooperation, developing alliances on Greek national interests, exploiting the EEZ which sets Greece on a conflict pattern with Turkey. All of the above of course are framed within international law. There are no references to Europe/EU with regards to national issuesinstead a subtle paradigm around increased national sovereignty is observed. This is even more pronounced for the Independent Greeks (ANEL): the main paradigm in the deep core is "national sovereignty" and "the Nation" whereas in their narrative they use words such as "treason" (targeted towards PASOK and ND) and "lies", while dominant words include "Hellenic" and "Greeks". They also try to emphasize this paradigm more with references to the Orthodox Church and they set themselves against Germany as Greece's main enemy.

The biggest interest in the new populist paradigms in foreign policy emerged in the manifesto of Golden Dawn. All the above paradigms that the right-wing parties adopt are enhanced in the nationalist socialist framework and the blame shifting goes towards all systemic parties. National issues are expanded to the Aegean, Thrace, Macedonia and Albania. The deep core paradigms are the "race" "to Greeks by descent", and the "cultural alteration". At the policy core policies are located against illegal immigrants (deportation), the annexation of Northern Epirus (South Albania) and the expansion of the EEZ. In the secondary aspects, it is interesting to observe the promotion of the 
Greek cultural paradigm as "superior" and the reference to an American and Turkish "sub-culture". Finally as a policy tool they suggest the foundation of a "research centre of anti-Hellenic activities" - as such Golden Dawn's proposals move around an ethnocentric far-right paradigm.

As the only centrist party, PASOK is interesting, because it maintains the populist competition, this time against SYRIZA as an immediate threat to PASOK's electoral success. However, in foreign policy issues, PASOK does not deviate from the previous paradigms of the European trajectory, national coordination and consensus building and international law. This is an important element since the party that brought populist paradigms in the Greek party system appears to be the least populist and the one using it the least in the double 2012 elections.

On the other side of the spectrum, left-wing parties maintain a populist paradigm. More specifically, KKE does not change its paradigm positioning apart from shifting the blame to SYRIZA and ND, emphasizing the exit from the one-way street of Europe - in essence saying that there should be national sovereignty but with a favourable popular aspect against class issues. SYRIZA presented in 2012 a wider framework of foreign policy that highlights its deep core peace and equal distances. It emphasized at the core of foreign policy UN principles and multilateralism in the Balkans and brought forward a solution to the name of North Macedonia. In the secondary aspects, it proposed the reduction of defence and military spending as well as the disentanglement of the country from military missions in the Middle East and Afghanistan.

As such then, in the elections of 2012, the binaries of populism that widen in the context of the financial crisis, begin to infiltrate foreign policy lines as these appear on the parties' manifestos. The establishment of extreme positions in foreign policy introduced the populist paradigm of far-right nationalism and patriotism expressed in various shades not only by the Golden Dawn but also by ANEL and ND. In sum, there is a general shift of foreign policy paradigms trying through populist ideological vehicles (e.g. the explicit division of "them" versus "us" and the targeting of appropriating elites) to convince voters that even in issues of foreign policy there is a sell-off of the homeland and jingoism.

\section{Elections 2015}

In 2015, two electoral contests took place as well; one in January and one in September. Many of the party positions did not change in between the two contests, it is interesting however to observe changes from 2012. The intensification of the migration crisis and the refugee influx in Europe, and the cooperation of SYRIZA and ANEL in government are indicative events to push change. At the same time a chapter in political change closes: SYRIZA has fully displaced PASOK as a pole of attracting voters and its paradigms start 
spilling over into the centre ground, traditionally "owned" by PASOK. ND on the other hand returned to Europeanism, while ANEL and GD intensified their far-right populism in national issues competing for votes of the extreme right.

In the context of its governing programme now, SYRIZA decreased the targeting of ND and PASOK in foreign policy issues and began to concentrate on the "external" enemy: the EU and neoliberal Germany. At the same time, SYRIZA decreased the use of populist paradigms from 2009 and 2012 and adopted a more conventional policy paradigm based in its deep core on the promotion and respect of rights, wider consensus-building, international law and multilateral foreign policy. The policy core included the disdain of "geopolitical obsessions", the European integration of the Balkans, a compound name for FYROM, energy agreements, the effectiveness of the armed forces, solution to the Cyprus issue on the basis of reunification, and the Diaspora. Regarding secondary aspects, there are references to a sustainable defence industry, energy diplomacy, tourism and cultural diplomacy, while SYRIZA seeks alliances with Russia and the wider Mediterranean region. The development of this more conventional paradigm began to resemble that of PASOK in 2009 and is in line with expectations set out by Mair (2009) as shifting from a populist party responsive to the demands of the people to a responsible party for government. On the contrary, KKE as the only remaining anti-system party of the left in parliament continued with its populist paradigm in the same direction, targeting not only PASOK and ND but also SYRIZA alongside the EU. Its policy core paradigm was still based in the disentanglement from the EU and NATO and any "imperialist warmongering alliances" highlighting the country's sovereign rights and the rejection of intervention against the peoples of the world.

It is worth mentioning the policy paradigm by PASOK: without populist shades it moved in the context of pacifism, democratic principles, and international growth at its deep core. In the policy core, it presented a multilateral and multidimensional policy with cooperation on issues of migration. Greece is presented as a "patriotic force" aiming at inter-regional cooperation in the Mediterranean, the solution of Greek-Turkish conflicts through the UN and the EU, the promotion of a solution to the naming of FYROM and the Cyprus issue, including in its toolkit, energy diplomacy, defence shielding with rationalisation of spending and an opening towards the US, Russia and China.

On the other side of the political spectrum, ND has completely discarded PASOK over SYRIZA when it comes to blame-shifting, returning to a new type of two-party paradigm and Europeanism, and projecting a more centre-right approach to foreign policy. Hence in its deep core ND advocated stability and growth but using at the same time the populist paradigm of "homeland" and the 
"tidy homemakers" for citizens, holding a light-touch ethnocentric popular character. In the policy core, ND projects national strategic planning and the rule of law, the guarding of the borders and the "returns" (instead of deportations) of illegal migrants. It also opposed the upgrading of FYROM as an EU border as well as the open border logic of Greece. In the secondary aspects, it referred to the organization of FRONTEX, establishing a Council of National Security for crisis management and creating a European Coastguard.

Populism was more evident in the right wing parties of the fringes of the system. ANEL shed their blame to the whole system using the notion of the "homeland" while they spoke of a national "sell-off", closed borders and full control of migration, as well as of "protecting national wealth" with a general slogan of "Greece belongs to Greeks" making a direct reference to a catch phrase used by socialist Andreas Papandreou and waking the memory of voters. In its deep core, ANEL brought up a "patriotic foreign policy" and in the policy core Thrace, Macedonia, the Cyprus issue and the unbreakable relation of the Church and the State. In the secondary aspects, ANEL presented populist paradigms in the form of opposition to the Turkish consulate in Thrace, the defence of a message on "a single, Greek, and non-negotiable Macedonia", the denouncement of the Turkish Republic of Northern Cyprus, as well as the cultivation of the "Ethnos" and the Christian Orthodox beliefs. Golden Dawn took these paradigms further to the edges accepting a deep core of nationalism and "cleansing" in foreign policy. It placed at the policy core notions of national independence and "strategic depth" based on the expansion of the water borders, nationalised exploitation of the seabed inside the EEZ, deportation of all immigrants, mandatory service for men and women in the army, as well as the detention of foreigners in some sort of concentration camps for criminal actions.

In general, although a relative convergence of the largest electoral poles is observed towards a more mainstream handling of foreign policy issues in the 2015 elections, there is also a considerable parallel populist polarization from the anti-systemic parliamentary parties present throughout the Greek financial crisis in terms of the use of policy paradigms. This binary seemed to have an ideological foundation, but it was also strategic in nature, given the rallying back of voters around two main party formations (ND and SYRIZA this time). ${ }^{6}$

${ }^{6}$ Since the period between 2009 and 2015 is taken as a basis in this article, current developments in Greek politics are not included. However, studies on these parties after 2015 have shown that the parties continue to maintain their political narratives on foreign policy through populism. For current studies on populism in Greek political parties, see Stavrakakis, Andreadis and Katsambekis (2017), Stavrakakis and Katsambekis (2019), and Andreadis and Stavrakakis (2017). 


\section{Concluding remarks}

The main objective of this article was the presentation of a different perspective on foreign policy narratives based on the concept of a "paradigm", i.e. the system of norms, values and beliefs that run through the axes of the deep core, policy core and secondary aspects of foreign policy. These paradigms are translated into policy action or intention for foreign policy making. Looking at these paradigms through the prism of populism helps observe the development of interesting narratives for foreign policy by every political party either on the basis of ideology or political tactics. In this context, populism is based on the division of the elites and the people using a mechanism of blame-shifting and responsibility exclusion.

The Greek financial crisis from the elections of 2009 until the elections of 2015 highlighted the existence of populist paradigms in foreign policy from all parliamentary parties across all electoral contests via their manifestos. The elections of 2012 can be considered as the culmination of populism, locating populist paradigms in all parties. These paradigms are manifested through narratives that shed the blame and introduce nationalism as a policy frame. However, the destabilised party system seemed to be finding an equilibrium on a new binary of ideological nature much like in the past, but this time with extreme populism moving on the frames of demarcation of "the people" and "the nation". The main conclusion therefore, is that the further increase of populism in foreign policy forms the future foundation of foreign policy debates in party competition. The findings also demonstrate the burgeoning of populist paradigms in the foreign policy narratives from the status quo and into the financial crisis, suggesting that despite foreign policy being considered a relative stable policy sector, the entrenchment of populism in the public sphere managed to penetrate even the deepest of the core beliefs in foreign policy, even bringing Greece in a collision track with its neighbours and inciting nationalist tendencies. Yet, the most important conclusion, is that the presence of populist parties with serious chances for electoral success create the perfect conditions for polarisation to increase and push all parties in the system to adopt a narrative on foreign policy issues that is more aligned with the positions of the populist parties at the extremes of the political spectrum rather than presenting a middle ground, more conciliatory narrative. Still, in the case of Greece and as a result of the overhaul of the party system, once the replacement of PASOK was completed by SYRIZA as the second political cluster, mainstreaming returned. Nonetheless, precisely because SYRIZA continued its populist narrative in foreign policy, and cooperated with the far-right ANEL, a degree of the polarised narrative remained present.

This article stops the analysis at the electoral contests of 2015. This is an important turning point in Greek politics as the turbulence created by the 
financial crisis began to subside. In fact, the elections of 2019 were caused by disagreement between SYRIZA and ANEL that split the coalition, and the inability of SYRIZA to maintain a workable majority. The advent of New Democracy to power however, was not accompanied by populist framing of the financial crisis itself but rather by the aftermath. Still, populism has not subsided and may have been further affected by developments in foreign policy that involved Greece. For example, the continuing destabilization of the Middle East, Turkey's assertive involvement in the Eastern Mediterranean, the recent conclusion of the name negotiations with North Macedonia as well as the context of the pandemic will create the short-term action framework for political actors domestically. These events also create the conditions to cultivate further populist paradigms in activities such as protests and direct violence against political actors. They also maintain national irredentism as well as the reification of the past to promote political goals. Both these elements merit further research especially in mapping out narratives against policy actions. 


\section{References:}

Allen, D. (1998) "Who speaks for Europe? The search for an effective and coherent external policy", in J. Peterson and H. Sjursen (ed.), A Common Foreign Policy for Europe?, (London: Routledge), pp. 41-58.

Andreadis, I. and Stavrakakis, Y. (2017) "European Populist Parties in Government: How Well are Voters Represented? Evidence from Greece", Swiss Political Science Review, 23(4): 485-508.

Barr, R. (2018) "Populism as a political strategy" in C. de la Torre (ed.), Routledge Handbook of Global Populism, (London: Routledge), pp. 44-56.

Béland, D. (2005) "Ideas and social policy: An institutionalist perspective", Social Policy and Administration, 39(1): 1-18.

Berman, S. (1998) The Social Democratic Moment: Ideas and Politics in the Making of Interwar Europe, (Cambridge, MA: Harvard University Press).

Biscop, S., Francioni, F., Graham, K. and M. Ortega (2005) "The European Union and the United Nations: partners in effective multilateralism", Chaillot Paper No. 78, Paris: Institute for Security Studies.

Cadier, D. and Lequesne C. (2020) "How Populism Impacts EU Foreign Policy", Policy Paper Series No:8.

Chryssogelos, A. (2017) "Populism in Foreign Policy", Oxford Research Encyclopedias-Politics, Published online, DOI: https://doi.org/10.1093/acre fore/9780190228637.013.467.

Diez, T. (2005) "Constructing the self and changing others: Reconsidering normative power Europe", Millennium, 33(3): 613-36.

Exadaktylos, T. (2012) "Europeanization of foreign policy beyond the common foreign and security policy", in T. Exadaktylos and C. M. Radaelli (eds.), Research Design in European Studies: Establishing Causality in Europeanization, (Basingstoke: Palgrave Macmillan), pp. 195-220.

Exadaktylos, T. (2015) "Changing Policy Paradigms" in Jørgensen, K. E., Drieskens, E., Kalland Aarstad, A., Laatikainen, K., and Tonra, B. (eds.), The SAGE Handbook of European Foreign Policy, $2^{\text {nd }}$ edition, (London: Sage).

Exadaktylos, T. and N. Zahariadis (2014) "Quid pro Quo: Political Trust and Policy Implementation in Greece during the Age of Austerity," Politics \& Policy, 42(1): 160-83.

Exadaktylos, T. and R. Nezi (2018) "Acceptance of austerity policies: evidence from a survey experiment in Greece", Paper presented at the ECPR Standing Group on European Union Conference, Paris 13-15 June 2018. 
Featherstone, K. (2011) "The Greek Sovereign Debt Crisis and EMU: A Failing State in a Skewed Regime", Journal of Common Market Studies, 49(2):193217.

Gidron, N. and B. Bonikowski, (2013) "Varieties of Populism: Literature Review and Research Agenda", Weatherhead Center for International Affairs Working Paper, No. 13-0004, 13-15.

Goldstein, J. and Keohane, R. O. (eds.) (1993) Ideas and Foreign Policy: Beliefs, Institutions and Political Change, (Ithaca, NY: Cornell University Press).

Haas, E. B. (1990) When Knowledge is Power, (Berkeley, CA: University of California Press).

Haas, P. M. (ed.) (1992) "Knowledge, power, and international policy coordination", International Organization, 46(1): 1-35.

Hall, P. A. (1993) "Policy paradigms, social learning and the state", Comparative Politics, 25(3): 275-96.

Hellenic Parliament (2020) Election Results, $<$ https://www.hellenicparliament. gr/en/Vouli-ton-Ellinon/To-Politevma/Ekloges/Eklogika-apotelesmataNew/>, (15 December 2020).

Hood, C., Jennings, W., Dixon, R., Hogwood, B. and Beeston, C. (2009) "Testing Times: Exploring Staged Responses and the Impact of Blame Management Strategies in Two Examination Fiasco Cases", European Journal of Political Research, 48(6): 695-722.

Howorth, J. (2004) "Discourse, ideas, and epistemic communities in European security and defence policy", West European Politics, 27(2): 211-34.

Jagers, J. and Walgrave, S. (2007) "Populism as Political Communication Style: An Empirical Study of Political Parties' Discourse in Belgium", European Journal of Political Research, 46(3): 319-45.

Jobert, B. and Muller, P. (1987) L'état en action, (Paris: PUF).

Jorgensen, K. E. (ed.) (1997) European Approaches to Crisis Management, (The Hague: Kluwer International).

Katsanidou, A. and Lefkofridi, Z. (2020) "A Decade of Crisis in the European Union: Lessons from Greece”, Journal of Common Market Studies, 58(1): 160-72.

Kaarbo, J. (1996) "Power and Influence in Foreign Policy Decision Making: The Role of Junior Coalition Partners in German and Israeli Foreign Policy”, International Studies Quarterly, 40(4): 501-30.

Kaarbo, J. (2008) "Coalition Cabinet Decision Making: Institutional and Psychological Factors”, International Studies Review, 10(1): 57-86. 
Kaarbo, J. (2012) Coalition Politics and Cabinet Decision Making: A Comparative Analysis of Foreign Policy Choices, (Ann Arbor: University of Michigan Press).

Kirchner, E. J. (2006) "The challenge of European Union security governance", Journal of Common Market Studies, 44(5): 947-68.

Levy, J. S. (1994) "Learning and foreign policy: Sweeping a conceptual minefield", International Organization, 48(2): 279-312.

Lucarelli, S. and Manners, I. (eds.) (2006) Values and Principles in European Union Foreign Policy, (London: Routledge).

Mair, P. (2009) "Representative versus Responsible Government", Max Planck Institute Working Paper 09/8.

Mudde, C. (2004) “The Populist Zeitgeist”, Government and Opposition, 39(4): 541-63.

Mudde, C. and Kaltwasser, C. R. (2012) "Exclusionary vs. Inclusionary Populism: Comparing Contemporary Europe and Latin America", Government and Opposition, 48 (2):147-74.

Mitsopoulos, M. and Pelagidis, T. (2011) Understanding the Crisis in Greece: From Boom to Bust, (Basingstoke, Palgrave Macmillan).

Plagemann J. and Destradi S. (2019) "Populism and Foreign Policy: The Case of India" Foreign Policy Analysis, 15(2): 283-301.

Pappas, T. (2013) "Why Greece Failed”, Journal of Democracy, 24(2):31-45.

Pappas, T. (2014) "Populist Democracies: Post-Authoritarian Greece and PostCommunist Hungary", Government and Opposition, 49(1):1-23.

Radaelli, C. M. (1998) "Networks of expertise and policy change in Italy", South European Society and Politics, 3(2): 1-22.

Sabatier, P. A. (1998) "The advocacy coalition framework: Revisions and relevance for Europe", Journal of European Public Policy, 5(1): 98-130.

Sabatier, P. A. and Jenkins-Smith, H. C. (1999) "The advocacy coalition framework: An assessment", in P. A. Sabatier (ed.) Theories of the Policy Process, (Boulder, CO: Westview Press), pp. 117-66.

Schmidt, V. A. (2002) "Does discourse matter in the politics of welfare state adjustment?", Comparative Political Studies, 35(2): 168-93.

Smith, K. E. (1999) The Making of EU Foreign Policy: The Case of Eastern Europe, (London: Macmillan).

Smith, K. E. (2006) "Speaking with one voice? European Union co-ordination on human rights issues at the United Nations", Journal of Common Market Studies, 44(1): 113-37. 
Smith, M. E. (2004) "Toward a theory of EU foreign policy-making: Multilevel governance, domestic politics, and national adaptation to Europe's common foreign and security policy", Journal of European Public Policy, 11(4): 740-58.

Stavrakakis, Y., Andreadis, I. and Katsambekis, G. (2017) "A new populism index at work: identifying populist candidates and parties in the contemporary Greek context", European Politics and Society, 18(4): 44664.

Stavrakakis, Y. and Katsambekis, G. (2019) “The populism/anti-populism frontier and its mediation in crisis-ridden Greece: from discursive divide to emerging cleavage?", European Political Science, 18(1): 37-52.

Surel, Y. (2000) "The role of cognitive and normative frames in policymaking”, Journal of European Public Policy, 7(4): 495-512.

Taggart, P. (2000) Populism, (Buckingham: Open University Press).

Tonra, B. and Christiansen, T. (ed.) (2004) Rethinking European Union Foreign Policy, (Manchester: Manchester University Press).

Vasilopoulou, S., Exadaktylos, T. and Halikiopoulou, D. (2014) "Greece 20092011: austerity, populism and the politics of blame," Journal of Common Market Studies, 52(2): 388-402.

Verbeek, B. and Zaslove, A. (2015) "The impact of populist radical right parties on foreign policy: the Northern League as a junior coalition partner in the Berlusconi Governments". European Political Science Review, 7(4): 52546.

Wehner, L. E. and Thies, C. G. (2020) "The nexus of populism and foreign policy: The case of Latin America", International Relations. Published online ahead of print, 24 July 2020, DOI: https://doi.org/10.1177/0047117820944430.

Weyland, K. (2001) "Clarifying a Contested Concept: Populism in the Study of Latin American Politics”, Comparative Politics, 34 (1): 1-22.

Wojczewski, T. (2020a) "Trump, Populism, and American Foreign Policy", Foreign Policy Analysis, 16(3): 292-311.

Wojczewski, T. (2020b) "Populism, Hindu Nationalism, and Foreign Policy in India: The Politics of Representing "the People", International Studies Review, 22(3): 396-422. 